\title{
Study on the Integration of Traditional Music Culture in Vocal Music Teaching
}

\author{
Jiang Shanshan \\ Heihe College, Heilongjiang, China
}

Keywords: vocal music teaching; traditional music culture; integration

\begin{abstract}
This paper, starting from the study of music pedagogy, discusses how to strengthen the traditional music culture education in the vocal music teaching of the music education in normal colleges and universities. First, this paper expounds the urgency of strengthening the traditional music culture education and the strategic hub position of the music education in the higher normal institutions in the early $21^{\text {st }}$ century, and emphasizes the significance of integrating the traditional music culture teaching in the teaching of the microskill teaching of music education. Further, this paper samples the vocal music teaching situation of Harbin Normal University and Northeast Normal University. It is pointed out that the present situation of the curriculum and teaching forms, the selection and use of teaching materials and the composition of teachers in the teaching of vocal music in the music education of normal colleges and universities show the characteristics of the Westernization of the "basement" in the whole.
\end{abstract}

\section{Introduction}

This article "discusses the integration of traditional music culture in the teaching of vocal music in Higher Teachers", the essence of which is to give a theoretical consideration to the issue of "strengthening the traditional music education in the teaching of vocal music in Higher Teachers". So, why should we strengthen the traditional music culture education, and should focus on the link of vocal music teaching in the music education of higher teachers? In the depth of this problem, we first request that we recognize the "strengthen the traditional music culture education", which has the strategic significance at the beginning of the century. Having a long history of traditional music culture, it is a valuable heritage and fine tradition of Chinese traditional culture. In thousands of years of development history, it plays a spiritual supporting role in maintaining national unity and national unity. Therefore, "strengthening traditional music culture and education" is the need to enhance national self-confidence and uplift the national spirit. Especially in twenty-first Century, we are in an era of global economic integration and cultural blending.

\section{The Integration of Traditional Music Culture in the Music Teaching}

\subsection{Teaching content}

In order to make up a set of teaching materials which can fully embody the teaching concept of "the integration of traditional music culture", the author believes that the following points must be fully considered. First, the active participation of music educationists and senior teachers, especially the excellent "folk song teachers", is not spoken. And it's a metaphor. But when considering the candidates, it is better to consider the cultural and cultural background of the traditional music as far as possible. At least, in the teaching concept, it can consciously realize the importance of the teaching of national vocal music and the inheritance of traditional music culture. Secondly, the core of the teaching idea is to strengthen the integration of traditional music culture in all aspects of vocal music teaching, which is the core of the "teaching mode of vocal music teaching emphasizing the integration of traditional music culture". The participation of senior national musicologists with profound traditional music and cultural quality. They are usually very good at making comparative thinking between multiculturalism, and are good at the analysis of music related to culture. Familiar 
with the Chinese traditional music and the Chinese minority music of the vocal music and their characteristics and cultural connotations, they should not only be the participants, but also play some leading role in the whole process of selection. Finally, we should also consider the participation of psychologists. They are especially good at the teaching psychology of teachers and the analysis of students' learning psychology. They can help us grasp the progress of teaching so as to choose the music and content which is more suitable for students in different grades.

\subsection{Teaching methods}

The purpose is to answer what should be taught in the "vocal music teaching mode of normal universities" which emphasizes the integration of traditional music culture. At present, the vocal music required courses in the "small classroom" of normal universities usually take Chinese and foreign art songs as the main content of teaching. On the one hand, this situation is related to the restriction of knowledge structure of vocal teachers in normal universities, because it is impossible to request every vocal music in normal universities. Teachers can sing "original flavor" folk songs or opera songs. On the other hand, the main purpose of the teaching of vocal music skills is to cultivate students' ability to sing vocal music. The teaching of art songs is no doubt more conducive to training and training students to master good vocal singing skills. Therefore, in the teaching content, in the vocal music teaching of the "small class" in Teachers' teachers' teachers, it is indisputable that the traditional music, such as art songs, "flow" and "chemical", is the main content of the teaching. This is not in conflict with our teaching idea of strengthening the integration of traditional music culture. However, as pointed out in the "current situation investigation and summary" in the previous article, the teaching of vocal music teaching in higher normal schools has the shortage of "heavy skill and light cultural connotation" in the teaching of these adapted folk songs and art songs, that is, to inherit the national characteristics of the singing method, but neglects the national style of the works. The understanding and learning of lingering charm and traditional culture.

\section{Integrating Traditional Music Culture into Vocal Music Teaching in Normal Colleges and Universities}

Music is a spiritual culture with its own charisma. As an institution of higher learning to foster humanistic spirit, inheriting culture is one of its important tasks. Colleges and universities are also the most concentrated places for music talents. They are the best research and protection of folk music.

The base of culture. However, because of many historical reasons, the teaching of vocal music in Colleges and universities has always followed the vocal music teaching system dominated by the professional music college, which is dominated by the sound of sound, and ignores the traditional Chinese vocal music culture. Then how to reflect the national characteristics and carry forward the Chinese music culture in college vocal music teaching? We believe that for vocal music teaching, it is necessary to inherit the most original national art, to highlight the national character, and to combine the popular singing forms with the classroom teaching in the folk. The teaching of vocal music in Colleges and universities should be as much as possible and ground to the ground. The following author will discuss teaching contents from three aspects: teaching objectives, teaching contents and teaching methods.

\subsection{The compiling adjustment in the contents of teaching materials}

In order to effectively the traditional music culture into the vocal music teaching, first of all to the material selection adjustment. Although there is no unified traditional music teaching material in our country, the higher normal colleges and universities in various places can select the teaching materials based on their own situation, based on the local cultural resources, and collect the traditional music works in many aspects and make a reasonable adaptation. Besides common traditional operas, we should increase the proportion of traditional works of original art, folk music and folk musical instruments. Only by firmly grasping the content of traditional characteristics can the students be educated effectively so that they can learn the true connotation of traditional music 
culture through learning. Carry out effective adjustment in the selection of teaching materials, in order to better the traditional music content into the vocal music education in the existing. With the increasing emphasis and devotion to art and culture in recent years, traditional music culture has attracted much attention. Domestic teachers colleges and universities have begun to do this work, but the theoretical construction of traditional music education standard system still needs a certain time.

\subsection{Adjust the teaching mode and change the teaching method}

The training objectives of all normal universities in China are high-quality music talents. The core of the training is vocal music learning. Generally speaking, the teaching content of vocal music is more important than the cultivation of students' vocal music skills. Teachers often adopt the teaching mode of group class, demonstrate the music of the music, concentrate on the music of various music creation schools, and pay attention to the guidance and exchange and interaction of special music works. In the group course, due to the constraints of various factors, the teacher's teaching of traditional music culture is only singing national vocal music works, and there is no extra time and energy to explain the traditional music cultural connotation in detail. Therefore, the author believes that, in view of the learning of traditional music culture, colleges and universities should appropriately change the inherent mode and promote the diversified teaching mode combining single class, group class and group class to improve the effect of teachers and students, students and students on the learning and communication of traditional music culture. Rate, let the students through the discussion and appreciation of traditional music culture, music culture each one airs his own views so as to improve the overall quality.

\subsection{Improve the professional accomplishment of teachers of vocal music}

Teachers play a leading role in the teaching of vocal music in higher teachers. Teachers need not only to teach students' skills and skills, but also to introduce their singing experience to students from their own experience in order to guide students to study effectively. Therefore, the teachers' professionalism directly affects the students' learning effect, which requires teachers to strengthen and improve their professional quality. By improving their cognition of traditional music culture and increasing the reserve of music knowledge, the traditional music culture and vocal music teaching are integrated reasonably. We can start from the following two aspects: one is to strengthen the learning of traditional cultural knowledge, improve the humanistic quality and learn more, and the two is to participate in academic exchanges, pay attention to the practice of art, and listen more. The only way to broaden academic horizons, guarantee the quality of teaching, and guide students.

\section{Conclusion}

At present, the present situation of the curriculum and teaching form, the selection and use of teaching materials, the composition of teaching materials and the composition of teachers in the teaching of music in Higher Teachers' music education, as a whole, shows the characteristics of the Westernization of the "base", and "the vocal teaching in the music education of the Teachers College as an important position in the implementation of the traditional music culture teaching." In order to train students to master the essential skills of vocal singing, we also emphasize the goal of strengthening their education and training of traditional musical culture. There is still a big gap. Of course, many people of insight have begun the thinking and practice exploration of "transformation". But everything is in preliminary exploration, and we need macro and systematic theoretical guidance urgently. To sum up, the teaching of vocal music in higher teachers needs the assistance of traditional music culture, and the inheritance of traditional music culture needs a platform. The organic combination of the two can not only guarantee the sound and sustainable development of vocal music teaching in normal universities, but also enable the traditional music culture to pass on and carry forward through the teaching platform of the teachers college. To achieve a win-win situation. 


\section{Acknowledgement}

Project source: key support project of Heihe University(16YSC03).

\section{References}

[1] Huang Wen. The integration of traditional musical culture into [J]. Drama House in college vocal music teaching, 2017 (09): 207-208.

[2] but Xia. Analysis of the integration of traditional music culture into [J]. art education in Normal University, 2017 (Z2): 90-91.

[3] Wen Ting. About the integration of traditional musical culture in vocal music teaching in Colleges and universities, [J]. Drama House. 2017, (02): 216-217.

[4] Wang Li. Analysis of the integration of traditional music culture in college vocal music teaching, [J]. music time and space, 2016 (06): 168-169.

[5] Liu Kun. The traditional music culture in vocal music teaching of [J]. voice of the Yellow River, 2016 (06): 21.

[6] Li Xiaoer. The integration of traditional musical culture music teaching, [J]. contemporary music, 2016 (03): 12-18. 